ISSN : 2252-3839 (Print)

ISSN : 2549-2403 (On Line)

DOI : 10.28989/compiler.v9i2.780

http://ejournals.stta.ac.id/index.php/compiler/

\title{
MEASURING THE WEBSITE QUALITY OF ADISUTJIPTO COLLEGE OF TECHNOLOGY BASED ON THREE DIMENSIONS (USABILITY, INFORMATION QUALITY AND SERVICE INTERACTION)
}

\author{
Dwi Nugraheny *, Yuliani Indrianingsih’ Aldio Bima Saifullah \\ Departemen Informatika Sekolah Tinggi Teknologi Adisutjipto Yogyakarta \\ Jl. Janti Blok R, Lanud Adisutjipto Yogyakarta \\ Email Corresponding : "henynug@gmail.com
}

Received: September 9, 2020; Accepted : October 10, 2020; Published : November 1, 2020

\begin{abstract}
Perceptions about the quality of education are the ability to provide an assessment of the superiority of an educational service that can produce academic and non-academic excellence for students by reffering to input, the process of outcomes and the impact it causes. One of the non-academic service on institutions to users, especially students is a website. One of the vision of educational institutions is to provide service to students electronically through website and be expected that the college website can provide the best possible information to students. This study discusses how to measure the website quality of Adisutjipto College of Tehcnology (STTA) using 3 (three) dimensions; Usability, Information Quality and Service Interaction. This research is a descriptive study with a survey method. The research instrument used a questionnaire. The research subjects were 50 STTA students. The results of the measurement survey which are affected by those three dimensions shows that the quality of the STTA's website is in the "Medium" category.
\end{abstract}

Keywords: Website Quality, Usability, Information Quality, Service Interaction.

\begin{abstract}
Abstrak
Persepsi tentang mutu pendidikan adalah kemampuan untuk memberikan penilaian atas keunggulan suatu layanan pendidikan yang dapat menghasilkan keunggulan akademik dan non akademik bagi peserta didik dengan mengacu pada masukan, proses hasil dan dampak yang ditimbulkannya. Salah satu layanan non akademik pada institusi kepada pengguna khususnya mahasiswa adalah website. Salah satu visi lembaga pendidikan adalah memberikan pelayanan kepada mahasiswa secara elektronik melalui website dan diharapkan website perguruan tinggi dapat memberikan informasi yang sebaik mungkin kepada mahasiswa. Penelitian ini membahas bagaimana mengukur kualitas website Sekolah Tinggi Teknologi Adisutjipto (STTA) dengan menggunakan 3 (tiga) dimensi; Kegunaan, Kualitas Informasi dan Interaksi Layanan. Penelitian ini merupakan penelitian deskriptif dengan metode survei. Instrumen penelitian menggunakan kuesioner. Subjek penelitian adalah 50 siswa STTA. Hasil survei pengukuran yang dipengaruhi oleh ketiga dimensi tersebut menunjukkan bahwa kualitas website STTA berada pada kategori "Sedang".
\end{abstract}

Kata Kunci: Kualitas Situs Web, Kegunaan, Kualitas Informasi, Interaksi Layanan. 


\section{Latar Belakang Masalah}

Daerah Istimewa Yogyakarta merupakan salah satu barometer pendidikan Nasional, sebagaimana diketahui bahwa Daerah Istimewa Yogyakarta dijuluki sebagai Kota Pelajar. Hal tersebut secara nyata wajar dikarenakan di tingkat Perguruan tinggi terdapat 110 Perguruan Tinggi yang terdiri dari 4 Perguruan Tinggi Negeri dan 106 Perguruan Tinggi Swasta (Data BPS 2017). Artinya kemajuan dan perkembangan pendidikan di tingkat perguruan tinggi secara pesat sudah berjalan baik di Kota Yogyakarta ini, baik dari segi Sumber Daya Manusia, pemanfaatan teknologi, pengembangan media pembelajaran dan managemen kampus dan pembelajaran.

Perguruan tinggi swasta adalah salah satu perguruan tinggi alternatif dalam menampung kebutuhan masyarakat terhadap kebutuhan pendidikan. Perguruan tinggi swasta berlomba-lomba bersaing guna mendapatkan mahasiwa sesuai jurusan yang ditawarkan. Selanjutnya berusaha untuk meningkatkan keunggulan dan pelayanan dalam usaha mewujudkan visi pendidikan nasional yaitu terselenggaranya layanan prima pendidikan nasional untuk membentuk insan Indonesia cerdas, komprehensif dan mengembangkan kemampuan serta meningkatkan mutu kehidupan dan martabat manusia.

Berkaitan dengan perkembangan teknologi informasi dan komunikasi yang sudah memasuki era teknologi 5.0, pelayanan lembaga pendidikan termasuk perguruan tinggi terhadap mahasiswa secara luas memanfaatkan kemajuan teknologi. Melalui pemanfaatan teknologi komunikasi dan informasi di dalam sektor pendidikan diharapkan dapat meningkatkan efisiensi, efektifitas, transparansi dan akuntabilitas penyelengaraan pendidikan. Salah satu tujuan dari institusi pendidikan adalah memberikan layanan kepada mahasiswa secara elektronik melalui media situs web dan diharapkan situs web perguruan tinggi dapat memberikan informasi kepada mahasiswa. Seperti halnya yang diungkapkan [1] menyatakan bahwa salah satu ciri sekolah yang bermutu adalah berfokus pada pelanggan, baik pelanggan internal maupun eksternal.

Popularitas teknologi Web dan aplikasinya digunakan oleh institusi pendidikan didukung oleh [2] menyebutkan bahwa perkembangan yang paling signifikan dalam era ini adalah pengembangan dari World Wide Web (WEB) dan [3] menyebutkan bahwa web adalah alasan utama internet dan membuat kinerja dengan lebih cepat atau dalam keadaan santai. Lebih lanjut [4] berpendapat bahwa keberadaan teknologi informasi sangat berguna untuk memudahkan pekerjaan secara efektif dan efisien. Menurut [5] bahwa Web browser adalah suatu perangkat lunak yang didesain untuk mencari dan membaca file di internet dalam format HTML atau Hyper Text Markup Language.

Salah satu domain dimana website paling banyak digunakan saat ini adalah domain akademik (Perguruan Tinggi/Universitas) [6]. Peranan website suatu universitas tidak hanya terbatas sebagai media informasi namun juga merupakan salah satu barometer yang dipakai untuk mengukur kualitas perguruan tinggi tersebut [7]. Website perguruan tinggi merupakan portal informasi yang diatur sebagai portal belajar dan dapat digunakan sebagai portal informasi bagi mahasiswa [8]. Sehingga dalam upaya penyelenggaraan pendidikan Indonesia yang kreatif, inovatif dan mendunia, sekolah dituntut untuk membuat sebuah website perguruan tinggi yang interaktif, mudah dinavigasi dan memiliki desain menarik [9]. 
Sekolah Tinggi Teknologi Adisutjipto (STTA) merupakan salah satu perguruan tinggi swasta yang berada di Provinsi Daerah Istimewa Yogyakarta, Kabupaten Bantul. Sekolah Tinggi Teknologi Adisutjipto (STTA) didirikan berdasar Keputusan Menteri Pendidikan Nasional Nomor : 124 /D/O/2001 tanggal 2 Agustus 2001. Secara operasional proses belajar mengajar dimulai pada tahun Akademik 2002/2003, bersamaan dengan selesainya pembangunan sarana dan prasarana tahap I. Sekolah Tinggi Teknologi Adsutjipto (STTA) memiliki 5 jurusan (Teknik Elektro, Teknik Industri, Teknik Informatika, Teknik Mesin, Teknik Penerbangan). Kegiatan STTA dalam bentuk Tri Dharma Perguruan Tinggi adalah melaksanakan Pendidikan dan Pengajaran, Penelilian, dan Pengabdian Pada Masyarakat. STTA diselenggarakan oleh Yayasan TNI Angkatan Udara Adi Upaya (Yasau).

Sebagai mana penjelasan di atas salah satu barometer yang dipakai untuk mengukur kualitas perguruan tinggi, Sekolah Tinggi Teknologi Adisutjipto (STTA) menggunakan domain akademik situs www.stta.ac.id. Domain atau portal ini digunakan sebagai media informasi juga berfungsi sebagai kegiatan akademik perkuliahan. Website Sekolah Tinggi Teknologi Adisutjipto (STTA) mempunyai menu yang terkait dengan tata kelola perguruan tinggi, diantaranya pendaftaran, berita dan kontak. Selain itu juga terdapat menu beranda, portal, profil, departemen, organisasi, layanan akademik dan situs e-learning.

Selama ini situs website Sekolah Tinggi Teknologi Adisutjipto (STTA) sudah memberikan pelayanan terhadap mahasiswa terkait media informasi dan perkuliahan melalui website dengan baik. Seberapa baik sebuah program dalam hal ini situs website perlu diukur kualitasnya sebagaimana barometer pengukuran kualitas perguruan tinggi. Pentingnya mengenali tentang pemanfaatan dan penggunaan website dari sisi pengguna merupakan alasan penelitian dilakukan. Kualitas tidak hanya berdasarkan sudut pandang dari penyedia layanan saja tetapi juga yang paling penting adalah persepsi pengguna. Seperti halnya penelitian yang pernah dilakukan oleh [10] tentang Analisis User Interface dan User Experience pada Website Sekolah Tinggi Teknologi Adisutjipto (STTA) Yogyakarta" menjelaskan bahwa hasil uji statistik dari para pengguna website STTA memiliki Usability dan Quality of Information (kualitas informasi) dengan kategori "Baik", serta memiliki Content, Pleasure, Classic Aesthetics, Expressive Aesthetics yang "Cukup".

Pada penelitian ini dibahas tentang Pengukuran Kualitas Website Sekolah Tinggi Teknologi Adisutjipto (STTA) berdasarkan 3 (tiga) dimensi yaitu kegunaan (usability), kualitas informasi (information quality) dan interaksi pelayanan (service interaction), nantinya bermanfaat sebagai rekomendasi kepada pengelola website Sekolah Tinggi Teknologi Adisutjipto (STTA) untuk peningkatan kualitas website.

\section{Metodologi Penelitian}

Penelitian ini merupakan penelitian deskriptif dengan metode survei. Instrumen penelitian menggunakan angket. Subjek penelitian adalah mahasiswa Sekolah Tinggi Teknologi Adisutjipto (STTA) berjumlah 50 mahasiswa. Teknik analisis data menggunakan analisis deskriptif presentase berdasarkan tiga dimensi yang mewakili kualitas suatu website, yaitu kegunaan (usability), kualitas informasi (information quality) dan interaksi layanan (service interaction).

\subsection{Pengukuran Kualitas Website}

Pendapat [11] bahwa kualitas merupakan hal dari sesuatu yang dipilih oleh pelanggan. Artinya kualitas berdasarkan pada dari pengalaman terhadap produk 
suatu penyedia jasa yang dapat berpedoman berdasarkan standar tertentu. Persepsi tentang kualitas dari pendidikan merupakan kemampuan memberikan penilaian terhadap keunggulan dari suatu layanan jasa pendidikan yang dapat menghasilkan keunggulan akademik dan non akademik pada mahasiswa dengan mengacu pada masukan, proses dari luaran, dan dampak yang disebabkan.

Webqual merupakan sebuah metode pengukuran kualitas website berdasarkan pengguna akhir. Metode ini merupakan sebuah metode pengembangan dari servqual [12] yang banyak digunakan sebelumnya pada pengukuran kualitas jasa. Instrumen penelitian pada Webqual tersebut dikembangkan dengan metode Quality Function Development (QFD), sedangkan [13] mengatakan bahwa "Website Quality adalah sebuah instrument yang dikembangkan untuk menilai kegunaan, informasi dan kualitas interaksi jasa dari website internet."

Instrumen yang digunakan pada penelitian ini adalah adalah instrumen dari [14] Webqual 4.0 yang terdiri dari 3 (tiga) komponen dimensi yaitu dimensi kegunaan, kualitas interaksi dan kualitas informasi. Total pertanyaan dari 3 (tiga) komponen dimensi tersebut sebanyak 22 butir pertanyaan, yang ditampilkan pada Tabel 1 .

Tabel 1. Dimensi dan Butir Pertanyaan Metode Webqual 4.0

\begin{tabular}{|c|c|}
\hline Dimensi & Webqual 4.0 Item \\
\hline Usability & $\begin{array}{l}\text { 1. Kemudahan untuk dioperasikan. } \\
\text { 2. Interaksi dengan website jelas dan dapat di mengerti. } \\
\text { 3. Kemudahan untuk navigasi. } \\
\text { 4. Kemudahan menemukan alamat website. } \\
\text { 5. Tampilan yang atraktif. } \\
\text { 6. Tepat dalam penyusunan tata letak informasi. } \\
\text { 7. Tampilan sesuai dengan jenis website pemerintahan. } \\
\text { 8. Adanya penambahan pengetahuan dari informasi website }\end{array}$ \\
\hline $\begin{array}{l}\text { Kualitas } \\
\text { Informasi }\end{array}$ & $\begin{array}{l}\text { 9. Menyediakan informasi yang cukup jelas. } \\
\text { 10. Menyediakan informasi yang dapat dipercaya. } \\
\text { 11. Menyediakan informasi yang up to date. } \\
\text { 12. Menyediakan informasi yang relevan. } \\
\text { 13. Menyediakan informasi yang mudah dipahami. } \\
\text { 14. Menyediakan informasi yang cukup detail. } \\
\text { 15. Menyajikan informasi dalam format yang sesuai. }\end{array}$ \\
\hline $\begin{array}{l}\text { Kualitas } \\
\text { Interaksi } \\
\text { Pelayanan }\end{array}$ & $\begin{array}{l}\text { 16. Mempunyai reputasi yang baik. } \\
\text { 17. Mendapatkan keamanan untuk melengkapi transaksi. } \\
\text { 18. Rasa aman dalam menyampaikan data pribadi. } \\
\text { 19. Kemudahan unutk menarik minat dan perhatian. } \\
\text { 20. Adanya suasana komunitas. } \\
\text { 21. Kemudahan untuk memberi masalah (feed back). } \\
\text { 22. Tingkatan kepercayaan yang tinggi atas informasi yang } \\
\text { disampaikan website. }\end{array}$ \\
\hline
\end{tabular}

\subsection{Populasi dan Sampel Penelitian}

Menurut [15], "Populasi ialah semua nilai baik hasil perhitungan maupun pengukuran, baik kuantatif maupun kualitatif, daripada karakteristik tertentu mengenai sekelompok objek yang lengkap dan jelas." Menurut [16] "Populasi adalah keseluruhan subjek penelitian." Populasi yang digunakan adalah mahasiswa STTA. 
Sampel adalah sebagian atau wakil populasi yang diteliti [16], serta [17] mengungkapkan bahwa sampel adalah sebagian dari jumlah dan karakteristik yang dimiliki oleh populasi. Sampel dalam penelitian ini berjumlah 50 mahasiwa yaitu $30 \%$ jumlah total populasi, diambil dengan cara purposive sampling. Kriteria yang digunakan adalah mahasiswa Sekolah Tinggi Teknologi Adisutjipto dan sudah mengakses Website Sekolah Tinggi Teknologi Adisutjipto (STTA).

\section{Hasil Penelitian dan Pembahasan}

Selanjutnya pada penelitian ini apabila dilihat dari 3 (tiga) dimensi, data dideskripsikan untuk mengetahui gambaran tentang penilaian pengguna dalam hal ini mahasiswa terhadap kualitas Website Sekolah Tinggi Teknologi Adisutjipto (STTA) yang diukur dengan metode survei menggunakan kuesioner yang berjumlah 22 butir dengan skala likert. Butir pertanyaan yang digunakan diisi secara daring oleh responden sebanyak 50 mahasiswa STTA. Kualitas website dijabarkan dalam 3 dimensi yaitu: dimensi kualitas kegunaan (usability), kualitas interaksi pelayanan (service interaction quality) dan kualitas informasi (information quality).

\subsection{Dimensi Kualitas Kegunaan (Usability)}

Data hasil penelitian mengenai dimensi kualitas kegunaan Website Sekolah Tinggi Teknologi Adisutjipto (STTA) yang terdiri dari 8 butir soal, diperoleh hasil sum $=1344$; skor minimum $=22$; skor maksimum $=40$; rerata $($ mean $)=29,86$, Standar Deviasi $(\mathrm{SD})=3,63$. Deskripsi tingginya dimensi kualitas kegunaan Website Sekolah Tinggi Teknologi Adisutjipto (STTA) dapat dilihat pada Tabel 2.

Tabel 2. Hasil Kualitas Website Sekolah Tinggi Teknologi Adisutjipto (STTA) Berdasarkan Dimensi Kualitas Kegunaan (Usability)

\begin{tabular}{|c|c|c|c|}
\hline Interval & Kategori & Frekuensi & Persentase \\
\hline $35,32<\mathrm{X}$ & Sangat Tinggi & 2 & $4,44 \%$ \\
\hline $31,68<\mathrm{X} \leq 35,32$ & Tinggi & 11 & $24,45 \%$ \\
\hline $28,05<\mathrm{X} \leq 31,68$ & Sedang & 19 & $42,22 \%$ \\
\hline $24,41<\mathrm{X} \leq 28,05$ & Rendah & 9 & $20 \%$ \\
\hline $\mathrm{X} \leq 24,41$ & Sangat Rendah & 4 & $8,89 \%$ \\
\hline \multicolumn{2}{|r|}{ Jumlah } & $\mathbf{4 5}$ & $\mathbf{1 0 0 \%}$ \\
\hline
\end{tabular}

Berdasarkan Tabel 2 di atas, bahwa kualitas Website Sekolah Tinggi Teknologi Adisutjipto (STTA) ditinjau dari dimensi Kualitas Kegunaan, masuk dalam kategori "sangat tinggi" sebanyak 2 responden atau sebesar 4,44\%, kategori "tinggi" sebanyak 11 responden atau sebesar 24,45\%, kategori "sedang” sebanyak 19 responden atau sebesar 42,22\%, kategori "rendah" sebanyak 9 responden atau sebesar $20 \%$ dan kategori "sangat rendah" sebanyak 4 responden atau sebesar $8,89 \%$.

Berdasarkan nilai rata-rata sebesar 29,86 bahwa Kualitas Website Sekolah Tinggi Teknologi Adisutjipto (STTA) ditinjau dari dimensi Kualitas Kegunaan (Usability) masuk dalam kategori "Sedang". 


\subsection{Dimensi Kualitas Interaksi Pelayanan (Service Interaction Quality).}

Data hasil penelitian mengenai dimensi Kualitas Interaksi Pelayanan Website Sekolah Tinggi Teknologi Adisutjipto (STTA) yang terdiri dari 7 butir soal, diperoleh hasil sum $=1117$; skor minimum $=19$; skor maksimum $=31$; rerata $($ mean $)=24,82$, Standar Deviasi $(\mathrm{SD})=2,97$. Deskripsi tingginya dimensi kualitas interaksi pelayanan Website Sekolah Tinggi Teknologi Adisutjipto (STTA) dapat dilihat pada Tabel 3 .

Tabel 3. Hasil Kualitas Website Sekolah Tinggi Teknologi Adisutjipto (STTA) Berdasarkan Dimensi Kualitas Interaksi Pelayanan

\begin{tabular}{|c|c|c|c|}
\hline Interval & Kategori & Frekuensi & Persentase \\
\hline $29,3<X$ & Sangat Tinggi & 4 & $8,89 \%$ \\
\hline $26,31<X \leq 29,3$ & Tinggi & 9 & $20 \%$ \\
\hline $23,32<X \leq 26,31$ & Sedang & 16 & $35,55 \%$ \\
\hline $20,34<\mathrm{X} \leq 23,32$ & Rendah & 13 & $28,89 \%$ \\
\hline$X \leq 20,34$ & Sangat Rendah & 3 & $6,67 \%$ \\
\hline \multicolumn{2}{|c|}{ Jumlah } & 45 & $100 \%$ \\
\hline
\end{tabular}

Berdasarkan Tabel 3 di atas, bahwa kualitas Website Sekolah Tinggi Teknologi Adisutjipto (STTA) ditinjau dari dimensi Kualitas Interaksi Pelayanan, masuk dalam kategori "sangat tinggi" sebanyak 4 responden atau sebesar $8,89 \%$, kategori "tinggi" sebanyak 9 responden atau sebesar 20\%, kategori "sedang" sebanyak 16 responden atau sebesar 35,55\%, kategori "rendah" sebanyak 13 responden atau sebesar 28,89\% dan kategori "sangat rendah" sebanyak 3 responden atau sebesar $6,67 \%$.

Berdasarkan nilai rata-rata sebesar 24,82 bahwa Kualitas Website Sekolah Tinggi Teknologi Adisutjipto (STTA) ditinjau dari dimensi Kualitas Interaksi Pelayanan (Service Interaction Quality) masuk dalam kategori "Sedang”.

\subsection{Dimensi Kualitas Informasi (Information Quality).}

Data hasil penelitian mengenai dimensi Kualitas Informasi Website Sekolah Tinggi Teknologi Adisutjipto (STTA) yang terdiri dari 7 butir soal, diperoleh hasil sum $=1168$; skor minimum $=18$; skor maksimum $=35$; rerata $($ mean $)=25,95$, Standar Deviasi (SD) $=3,33$. Deskripsi tingginya dimensi kualitas informasi Website Sekolah Tinggi Teknologi Adisutjipto (STTA) dapat dilihat pada Tabel 4.

Tabel 4. Hasil Kualitas Website Sekolah Tinggi Teknologi Adisutjipto (STTA) Berdasarkan Dimensi Kualitas Informasi

\begin{tabular}{|c|c|c|c|}
\hline Interval & Kategori & Frekuensi & Persentase \\
\hline $30,95<X$ & Sangat Tinggi & 4 & $8,89 \%$ \\
\hline $27,62<X \leq 30,95$ & Tinggi & 9 & $20 \%$ \\
\hline $24,29<X \leq 27,62$ & Sedang & 17 & $37,78 \%$ \\
\hline $20,96<X \leq 24,29$ & Rendah & 14 & $31,11 \%$ \\
\hline$X \leq 20,96$ & Sangat Rendah & 1 & $2,22 \%$ \\
\hline
\end{tabular}

Berdasarkan Tabel 4 di atas, bahwa kualitas Website Sekolah Tinggi Teknologi Adisutjipto (STTA) ditinjau dari dimensi Kualitas Informasi, masuk 
dalam kategori "sangat tinggi" sebanyak 4 responden atau sebesar 8,89\%, kategori "tinggi" sebanyak 9 responden atau sebesar 20\%, kategori "sedang" sebanyak 17 responden atau sebesar 37,78\%, kategori "rendah" sebanyak 14 responden atau sebesar 31,11\% dan kategori "sangat rendah" sebanyak 1 responden atau sebesar $2,22 \%$.

Berdasarkan hasil nilai rata-rata sebesar 25,95 bahwa Kualitas Website Sekolah Tinggi Teknologi Adisutjipto (STTA) ditinjau dari dimensi Kualitas Informasi masuk dalam kategori "Sedang". Sehingga apabila dilihat dari masingmasing dimensi (3 dimensi), hasil nilai rata-rata dapat dilihat pada Tabel 5.

Tabel 5. Hasil Kualitas Website Sekolah Tinggi Teknologi Adisutjipto (STTA) dilihat dari 3 (tiga) Dimensi

\begin{tabular}{|l|c|c|}
\hline \multicolumn{1}{|c|}{ Dimensi } & Nilai Rata-rata & Kategori \\
\hline Kualitas Kegunaan (Usability) & 29,86 & Sedang \\
\hline Kualitas Interaksi Pelayanan & 24,82 & Sedang \\
\hline Kualitas Informasi & 25,95 & Sedang \\
\hline
\end{tabular}

Berdasarkan Tabel 5 di atas, bahwa kualitas website Sekolah Tinggi Teknologi Adisutjipto (STTA) dapat diketahui berdasarkan 3 (tiga) dimensi yaitu Kualitas Kegunaan (Usability), Kualitas Interaksi Pelayanan dan Kualitas Informasi berada dalam kategori "Sedang" dalam hal

\section{Kesimpulan}

Penelitian Kualitas Website Sekolah Tinggi Teknologi Adisutjipto (STTA)

berdasarkan tiga dimensi yaitu kegunaan (usability), kualitas informasi (information quality) dan interaksi layanan (service interaction) disimpulkan sebagai berikut:

1. Hasil nilai rata-rata sebesar 29,86 bahwa Kualitas Website Sekolah Tinggi Teknologi Adisutjipto (STTA) ditinjau dari dimensi Kualitas Kegunaan masuk dalam kategori "Sedang".

2. Hasil nilai rata-rata sebesar 24,82 bahwa Kualitas Website Sekolah Tinggi Teknologi Adisutjipto (STTA) ditinjau dari dimensi Kualitas Interaksi Pelayanan (Service Interaction Quality) masuk dalam kategori "Sedang”.

3. Hasil nilai rata-rata sebesar 25,95 bahwa Kualitas Website Sekolah Tinggi Teknologi Adisutjipto (STTA) ditinjau dari dimensi Kualitas Informasi masuk dalam kategori "Sedang".

4. Dikarenakan kualitas website STTA hasil responden masuk kategori "Sedang" berdasarkan 3 (tiga) dimensi tersebut, maka kiranya untuk masa mendatang website STTA dapat masuk kategori "Tinggi".

\section{Daftar Pustaka}

[1] Sallis, E. (2014). Total quality management in education. Routledge.

[2] Rosandich, T. J. (2011). Information technology and sports: looking toward Web 3.0. The Sport Journal, 14(1), 1-13.

[3] Dix, A., Dix, A. J., Finlay, J., Abowd, G. D., \& Beale, R. (2003). Humancomputer interaction. Pearson Education. 
[4] Arifin, S. R. (2018). Pengukuran kualitas layanan website Universitas Tadulako menggunakan metode WebQual. Register: Jurnal Ilmiah Teknologi Sistem Informasi, 4(2), 125-136.

[5] Pearson, M. (2008). Sistem Informasi Manajemen. Salemba. Jakarta, 9.

[6] Kothainayaki, S., Sivakumaren, K. S., \& Gopalakrishnan, S. (2012). User preferences on university websites: a study. Library Philosophy and Practice, 1.

[7] Puspitasari, D., \& Widyobroto, B. P. (2013). Kajian Kepuasan Terhadap Website Universitas Airlangga: Studi Komparasi antara Pengguna Internal dan Pengguna Eksternal/Potensial. Under Graduates Thesis. Universitas Gadjah Mada.

[8] Taddeo, C., \& Barnes, A. (2016). The school website: Facilitating communication engagement and learning. British Journal of Educational Technology, 47(2), 421-436.

[9] Abdullah, D., Jayaraman, K., Kamal, S. B. M., \& Md Nor, N. (2016). A conceptual model of interactive hotel website: The role of perceived website interactivity and customer perceived value toward website revisit intention. Procedia Economics and Finance, 37(16), 170-175.

[10] Nugraheny, D. (2016, November). Analisis User Interface dan User Experience pada Website Sekolah Tinggi Teknologi Adisutjipto Yogyakarta. In Conference SENATIK STT Adisutjipto Yogyakarta (Vol. 2, pp. 183-187).

[11] Wijaya, T. (2011). Manajemen kualitas jasa. Jakarta: PT. Indeks, 143.

[12] Zeithaml, V. A., Berry, L. L., \& Parasuraman, A. (1996). The behavioral consequences of service quality. Journal of marketing, 60(2), 31-46.

[13] Muhsin, A., \& Zuliestiana, D. A. (2017). Analisis Pengaruh Kualitas Website (Webqual) 4.0 Terhadap Kepuasan Pengguna Bukalapak Di Kota Bandung. eProceedings of Management, 4(3).

[14] Barnes, S. J., \& Vidgen, R. (2003). Measuring web site quality improvements: a case study of the forum on strategic management knowledge exchange. Industrial management \& Data systems.

[15] Akbar, P. S., \& Usman, H. (2006). Pengantar Statistika Edisi Kedua. Jakarta: PT Bumi Aksara.

[16] Suharsimi, A. (2006). Prosedur penelitian suatu pendekatan praktik. Jakarta: Rineka Cipta.

[17] Sugiyono, M. P. P. P. K. (2007). Kualitataif dan R\&D, Bandung: Alfabeta, 2010. Sugiyono, Metode Penelitian Kuantitatif kualitatif dan $R \& D$ Bandung: Alfabeta.

[18] BPS. 2017. Jumlah Perguruan Tinggi, mahasiswa dan tenaga edukatif (Negeri dan Swasta) di Bawah Kementriaan Pendidikan dan Kebudayaan Menurut Provinsi tahun ajaran 2014/2015. https://www.bps.go.id/statictable/2015/09/14/1839/jumlah-perguruan-tinggimahasiswa-dan-tenaga-edukatif-negeri-dan-swasta-di-bawah-kementrianpendidikan-dan-kebudayaan-menurut-provinsi-2013-2014-2014-2015.html

[19] Dafid, D., \& Novita, D. (2018). Metode WebQual 4.0 Untuk Analisis Kualitas Web Pembelajaran. JTKSI (Jurnal Teknologi Komputer dan Sistem Informasi), 1(2), 17-21.

[20] Yodi, Y. (2018). Analisis Kualitas Situs Web Batampos Menggunakan Metode WebQual 4.0. Jurnal RESTI (Rekayasa Sistem dan Teknologi Informasi), 2(2), 591-596. 